\title{
Speed Control of DC Motor Using PID and Arduino
}

\author{
Zaw Ngwe*, Aye Aye Tun
}

Department of Electronic, Technological University, Maubin, Myanmar

\begin{abstract}
This paper is aim to research the Proportional Integral Differential (PID) controller design and selection of various Proportional, Integral and Differential control parameters. MATLAB is allows matrix manipulations, plotting of functions and data, implementation of algorithms. An additional package, Simulink, adds graphical multi-domain simulation and model-based design for dynamic and embedded systems. MATLAB is used to implement the Proportional Integral Differential (PID) controller, it is used to control the speed of $\mathrm{DC}$ motor and bring it at the desired speed. PID parameters $\mathrm{Kp}, \mathrm{Ki}$ and $\mathrm{Kd}$ are finely tuned to optimal values. And then a ARDUINO UNO microcontroller is programmed by adding the finely tuned PID algorithm to control the speed of DC motor.
\end{abstract}

Keywords: PID, MATLAB, Arduino Uno, DC Motor

\section{INTRODUCTION}

DC motor have been widely use in high-performance electrical drives. There are various differences DC motors in the market and all with it good and bad attributes. The bad motor is the lag of efficiency, and therefore to solve this problem a ProportionalIntegral-Derivative (PID) controller is designed in this paper. PI controller is a generic control loop feedback mechanism widely used in industrial control systems. A PI controller attempts to correct the error between a measured system variable and a desired set point. It is calculate and then outputting a corrective action that can adjust the system accordingly. So, by integrating the PI controller to the DC motor were able to correct the error made by the DC motor and control the speed of the DC motor to the desired speed.

\section{DC MOTOR}

A direct current or DC motor, converts electrical energy into mechanical energy. It is one of two basic types of motors: the other type is the alternating current or AC motor. Among DC motors, there are shunt-wound, series-wound, compound-wound and permanent magnet motors.

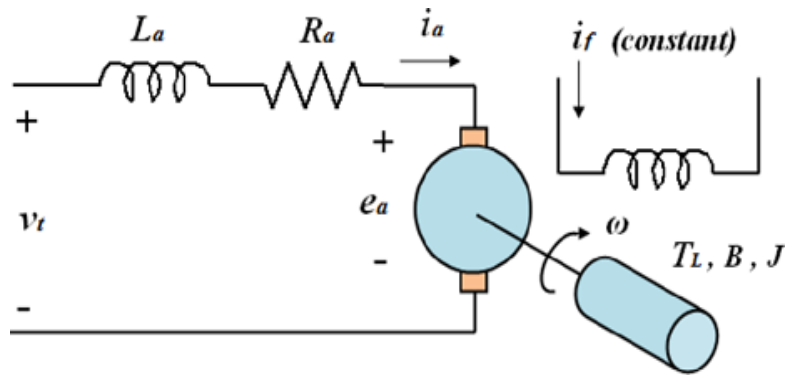

Figure 1. Electrical Circuit Diagram

In this thesis, it will assume the following values for the physical parameters of DC motor. 
Armature resistance $(\mathrm{Ra})=1 \Omega$

Armature inductance $(\mathrm{La})=0.4 \mathrm{H}$

Mechanical inertia $(\mathrm{j})=0.01 \mathrm{Kg} \cdot \mathrm{m}$

Friction coefficient $(\mathrm{B} \mathrm{m})=0.2 \mathrm{~N} \cdot \mathrm{m} / \mathrm{rad} / \mathrm{sec}$

Back emf constant $(\mathrm{k})=0.01 \mathrm{~V} / \mathrm{rad} / \mathrm{sec}$

\section{PID CONTROLLER}

A PID controller is an instrument used in industrial control applications to regulate temperature, flow, pressure, speed and other process variables. PID (proportional integral derivative) controllers use a control loop feedback mechanism to control process variables and are the most accurate and stable controller.

PID control is a well-established way of driving a system towards a desired speed. PID control uses closed-loop control feedback to keep the actual output from a process as close to the target or set point output as possible.

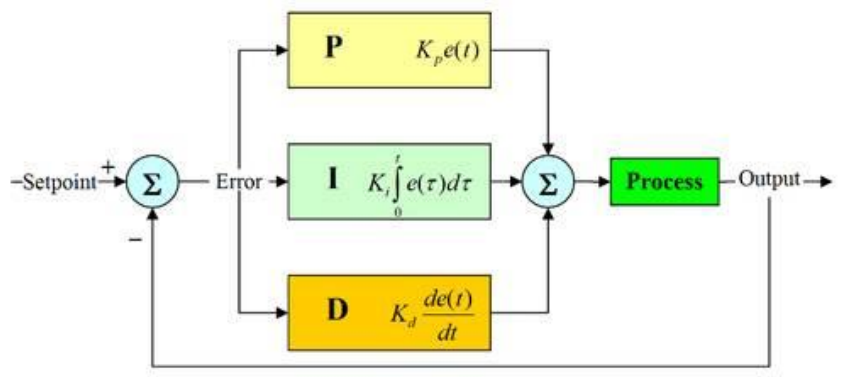

Figure 2. Simple Block Diagram of PID Controller

Using Laplace transforms, the above model equations can be expressed in terms of $s$.

$$
\begin{array}{ll}
\mathrm{S}(\mathrm{J} \times \mathrm{s}+\mathrm{b}) \times \theta(\mathrm{s})=\mathrm{k} \times \mathrm{i}(\mathrm{s}) & \text { equation (1) } \\
(\mathrm{L} \times \mathrm{s}+\mathrm{R}) \times \mathrm{i}(\mathrm{s})=\mathrm{V}-\mathrm{k} \times \mathrm{s} \times \theta(\mathrm{s}) . & \text { equation (2) }
\end{array}
$$

by eliminating $\mathrm{i}(\mathrm{s})$, it get the following open-loop transfer function.

$$
\theta / \mathrm{V}=\mathrm{k} /\left((\mathrm{J} \times \mathrm{s}+\mathrm{b}) \mathrm{x}(\mathrm{L} \times \mathrm{s}+\mathrm{R})+\mathrm{k}^{\wedge} 2\right) \text { equation (3) }
$$

$\mathrm{P}$-motor $=\mathrm{k} /\left(\left(j^{*} \mathrm{~s}+\mathrm{b}\right)^{*}\left(\mathrm{~L}^{*} \mathrm{~s}+\mathrm{R}\right)+\mathrm{K}^{\wedge} 2\right)$

$$
\mathrm{Gp}=
$$

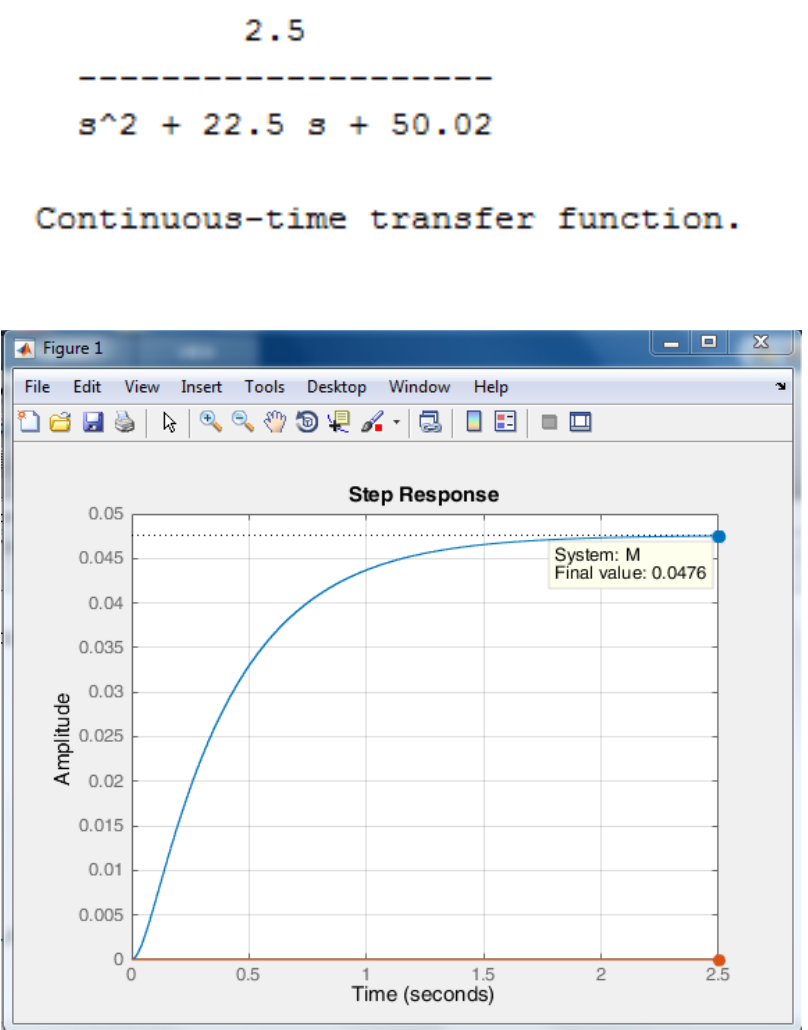

Figure 3. Open Loop Response

\section{PROPORTIONAL CONTROL}

A proportional controller is used to set $\mathrm{ki}=0, \mathrm{kd}=0$ in program. And it takes different values of $\mathrm{kp}$ the calculation results was assumed in Table 1, and the corresponding plots was gathered in Fig. 4:

Table 1

\begin{tabular}{|l|l|l|l|l|}
\hline Kp & $\begin{array}{l}\text { Rise } \\
\text { time } \\
(\mathrm{sec})\end{array}$ & $\begin{array}{l}\text { Maximum } \\
\text { overshoot } \\
(\%)\end{array}$ & $\begin{array}{l}\text { Steady } \\
\text { state } \\
\text { error }\end{array}$ & $\begin{array}{l}\text { Peak } \\
\text { amplitude }\end{array}$ \\
\hline 100 & 0.114 & 6.83 & 0.833 & 0.89 \\
\hline 200 & 0.0682 & 17.9 & 0.909 & 1.07 \\
\hline 300 & 0.144 & 17.9 & 0.909 & 1.07 \\
\hline
\end{tabular}


The proportional controller $\mathrm{kp}$ have the effect of reducing the rise time; and will reduce and never eliminate the steady state error. So, the response becomes more and more faster by increasing the gain $\mathrm{kp}$. But will increase the maximum overshoot.

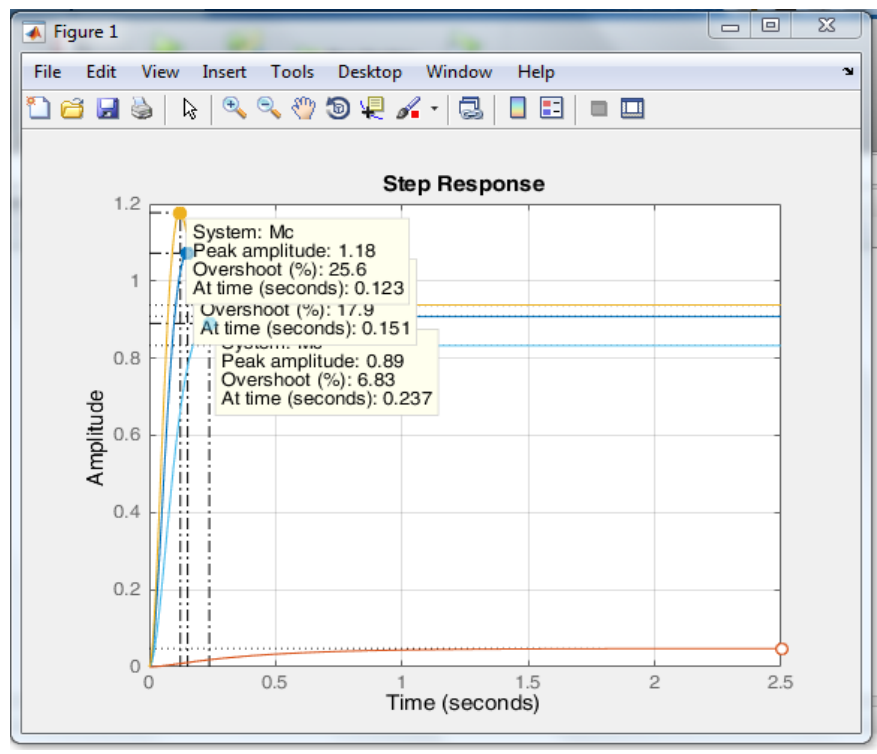

Figure 4. Closed Loop Response with Different Values of $\mathrm{kp}$

\section{PROPORTIONAL INTEGRAL CONTROL(PI)}

The settling is time still too long, it is need to increase the gain ki with $\mathrm{kp}=200$, all the results are shown in the Table 2. And the corresponding plot is gathered in Fig. 5.

Table 2

\begin{tabular}{|l|l|l|l|l|l|}
\hline Ki & $\begin{array}{l}\text { Setting } \\
\text { time(sec } \\
)\end{array}$ & $\begin{array}{l}\text { Rise } \\
\text { time } \\
(\mathrm{sec})\end{array}$ & $\begin{array}{l}\text { Maximu } \\
\mathrm{m} \\
\text { overshoo } \\
\mathrm{t}(\%)\end{array}$ & $\begin{array}{l}\text { Stead } \\
\mathrm{y} \\
\text { state } \\
\text { error }\end{array}$ & $\begin{array}{l}\text { Peak } \\
\text { amplitud } \\
\mathrm{e}\end{array}$ \\
\hline $\begin{array}{l}10 \\
0\end{array}$ & 2.86 & $\begin{array}{l}0.075 \\
4\end{array}$ & 10 & 1 & 1.1 \\
\hline $\begin{array}{l}20 \\
0\end{array}$ & 1.13 & $\begin{array}{l}0.073 \\
6\end{array}$ & 10 & 1 & 1.1 \\
\hline $\begin{array}{l}30 \\
0\end{array}$ & 0.419 & $\begin{array}{l}0.073 \\
6\end{array}$ & 10 & 1 & 1.1 \\
\hline
\end{tabular}

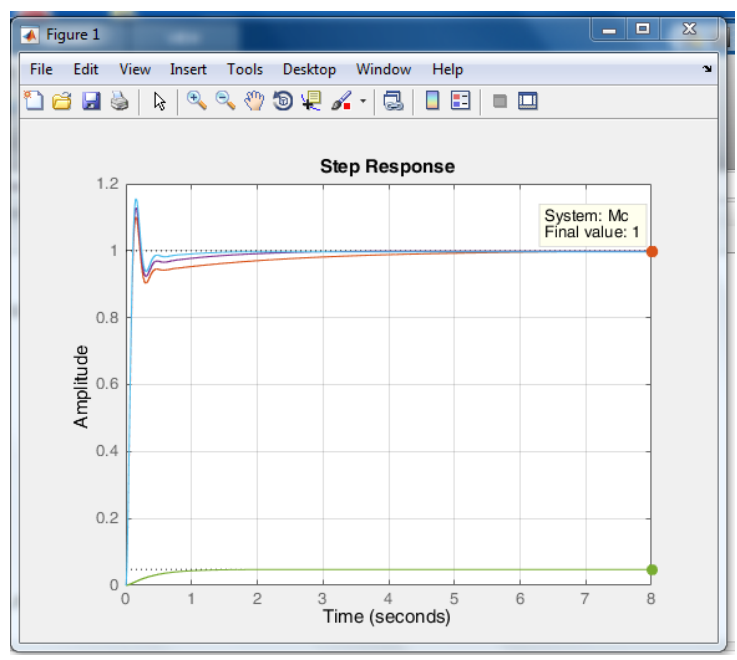

Figure 5. Closed Loop Response with Different Values of ki.

The response is much faster than before; the settling time becomes for $\mathrm{ki}=200$, and the steady-state error becomes very small and eliminated for $\mathrm{ki}=200$.

\section{PROPORTIONAL-INTEGRAL DERIVATIVE CONTROL (PID):}

It is need to increase the gain $\mathrm{kd}$, with $\mathrm{kp}=200 ; \mathrm{ki}=200$. All results are illustrated in the Table 3 and the corresponding plots are shown in Fig. 6.

Table 3

\begin{tabular}{|l|l|l|l|l|l|}
\hline Kd & $\begin{array}{l}\text { Setting } \\
\text { time(sec) }\end{array}$ & $\begin{array}{l}\text { Rise } \\
\text { time } \\
(\mathrm{sec})\end{array}$ & $\begin{array}{l}\text { Maximum } \\
\text { overshoot } \\
(\%)\end{array}$ & $\begin{array}{l}\text { Steady } \\
\text { state } \\
\text { error }\end{array}$ & $\begin{array}{l}\text { Peak } \\
\text { amplit } \\
\text { ude }\end{array}$ \\
\hline 3 & 0.475 & 0.0848 & 4.76 & 0 & 1.05 \\
\hline 7 & 0.478 & 0.0981 & 4.76 & 0 & 0.997 \\
\hline 10 & 0.478 & 0.0111 & 4.76 & 0 & 1.05 \\
\hline
\end{tabular}




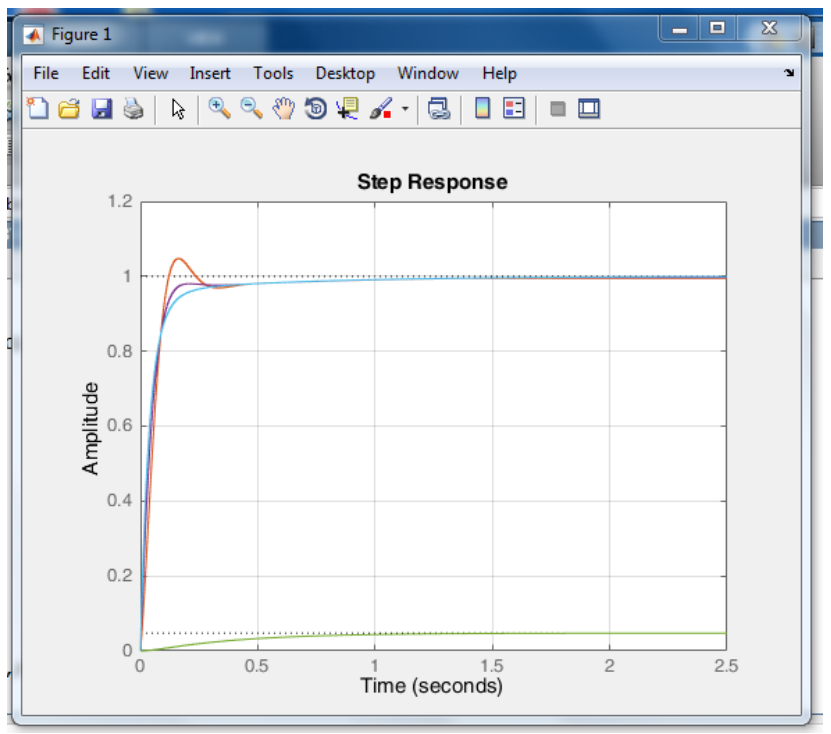

Figure 6. Closed Loop Response with Different Values of $\mathrm{kd}$

The pid controller with: $\mathrm{kp}=200, \mathrm{ki}=200$ and $\mathrm{kd}=10$; all are design requirements will be satisfied and the response looks like:

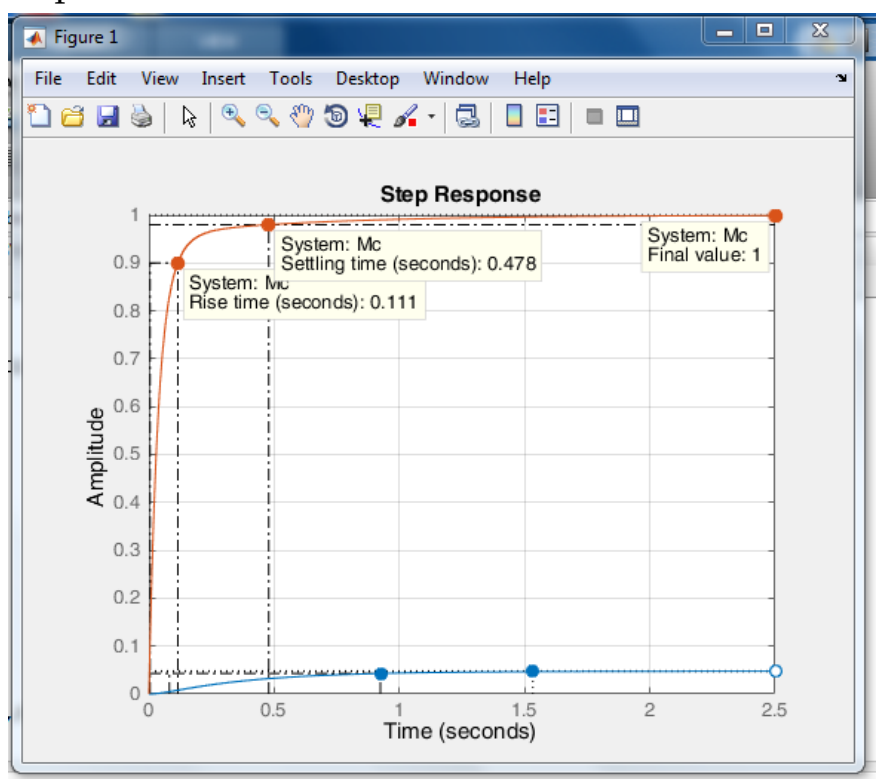

Figure 7. System Closed Loop Response with PID control

Effects of PID controllers parameters kp, ki and kd on a closed loop system are summarized in the table bellow.
Table 4

\begin{tabular}{|c|c|c|c|c|}
\hline $\begin{array}{l}\text { Closed } \\
\text { loop } \\
\text { respons } \\
\text { e }\end{array}$ & $\begin{array}{l}\text { Rise } \\
\text { time } \\
(\mathrm{sec})\end{array}$ & $\begin{array}{l}\text { Maximu } \\
\mathrm{m} \\
\text { overshoot } \\
(\%)\end{array}$ & $\begin{array}{l}\text { Setting } \\
\text { time(sec } \\
\text { ) }\end{array}$ & $\begin{array}{l}\text { Steady } \\
\text { state } \\
\text { error }\end{array}$ \\
\hline $\begin{array}{l}\text { as the } \\
\text { increase } \\
\text { of } \mathrm{kp}\end{array}$ & $\begin{array}{l}\text { decreas } \\
\mathrm{e}\end{array}$ & increase & $\begin{array}{l}\text { Small } \\
\text { change }\end{array}$ & decrease \\
\hline $\begin{array}{l}\text { as the } \\
\text { increase } \\
\text { of ki }\end{array}$ & $\begin{array}{l}\text { decreas } \\
\text { e }\end{array}$ & increase & increase & $\begin{array}{l}\text { eliminat } \\
\text { e }\end{array}$ \\
\hline $\begin{array}{l}\text { as the } \\
\text { increase } \\
\text { of } k d\end{array}$ & $\begin{array}{l}\text { Small } \\
\text { change }\end{array}$ & decrease & decrease & $\begin{array}{l}\text { Small } \\
\text { change }\end{array}$ \\
\hline
\end{tabular}

\section{VII.SIMULATION AND TEST}

The following figure 8 was designed with Arduino Uno, DC motor, L298 and variable resistor to control the motor speed in Proteus software. In order to do that, the physical parameters of DC motor are firstly identified. Plug these parameters value the transfer functions, open-loop step response curve is obtained. Then, PID controller was designed that will reduce the rise time, time and steady-state error.

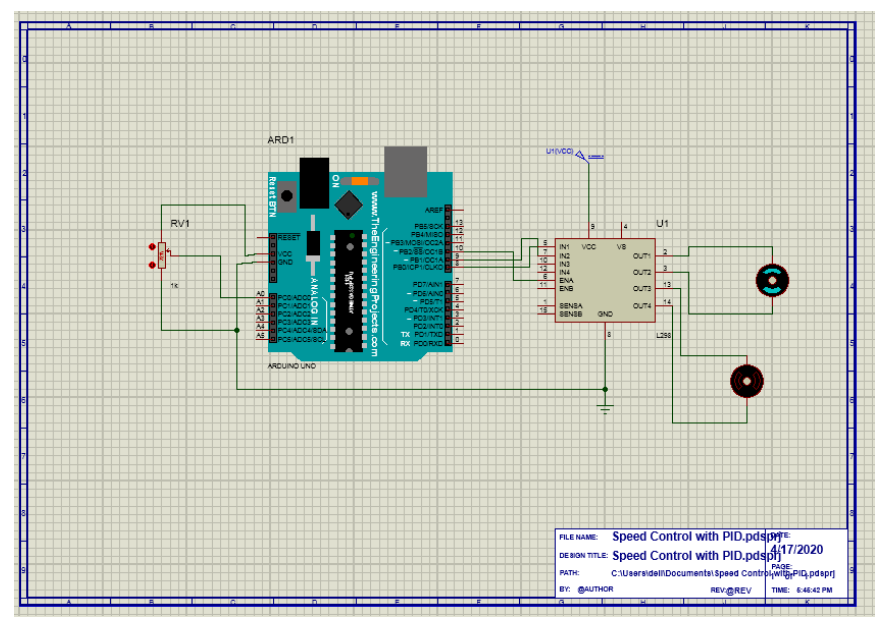

Figure 8. Simulation Test in Proteus 


\section{CONCLUSION}

The proportional controller $(\mathrm{kp})$ will have the effect of reducing the rise time and will reduce; but never eliminate the steady-state error, an integral control (ki) will have the effect of eliminating the steady-state error, but it may make the transient response worse .a derivative control $(\mathrm{kd})$ will have the effect of increasing the stability of the system, reducing the overshoot, and improving the transient response.

\section{REFERENCES}

[1]. Zhen-yu zhao ,Masayoshi Tomizuka ,and Satoru Isaka , “ Fuzzy gain of PID controller," Members,IEEE

[2]. Christopher T.kilian "Modern control technology: components and systems," 2end edition .

[3]. Robert H.Bishop, "Modern control system Analysis and Design Using MATLAB

\section{Cite this article as :}

Zaw Ngwe, Aye Aye Tun, "Speed Control of DC Motor Using PID and Arduino", International Journal of Scientific Research in Science and Technology (IJSRST), Online ISSN : 2395-602X, Print ISSN : 23956011, Volume 7 Issue 3, pp. 33-37, May-June 2020. Available

doi : https://doi.org/10.32628/IJSRST2072103

Journal URL : http://ijsrst.com/IJSRST2072103 